\title{
The Impact of Training and Development and Supervisors Support on Employees Retention in Academic Institutions in Pakistan: The Moderating Role of the Work Environment
}

\author{
Palwasha Bibi, $*$ Ashfaq Abmad, and Abdul Halim Abd.Majid \\ Universiti Utara Malaysia, Malaysia
}

\begin{abstract}
This study investigated the impact of training and development and supervisors support on employees retention. Furthermore, the current study also investigates the moderating effect of the work environment on the relationship between training and development, supervisors support, and employees' retention. A survey was undertaken to collect data from 250 faculty members working in public sector universities in Pakistan. PLS path modeling was employed to analyze the data. The results revealed that training and development and the support of the supervisors had a significant relationship with the retention of employees. Similarly, the results also revealed that the work environment moderated the relationship between training and development, supervisors support, and employees' retention. Finally, the implications, limitations and recommendations for further research were discussed.
\end{abstract}

Keywords: employee retention; supervisor support; training and development; work environment

JEL classification: M51, M53

* Corresponding author's e-mail: dr.palwashabibi@gmail.com 


\section{Introduction}

Employee retention is considered to be the foundation for the success of any organization (Osteraker 1999). Employee retention is a process through which employees are motivated to stay with the organization, and this is profitable for both the employees and the organization (Akila 2012). A higher retention rate avoids the expense of recruiting and training new employees, this saving can then be used for the employees' performance improvement measures (Abbasi and Hollman 2000). The vast majority of studies revealed that retaining their employees is a matter of grave concern for organizations, thus they use a diverse array of approaches to retain their employees (American Management Association 2001).

A declining rate of employee retention is one of the key challenges being faced by organizations, which is coupled with the intensified competition and increased mobility of highly skilled employees, caused by globalization (Ng'etheet al. 2012). Hence, retaining competent employees has become a big challenge for human resource managers, since competent employees have the luxury of choice in the global market (Harris 2007). According to Irshad and Afridi (2010), when an employee quits his/her job, the employer loses not only the employee, but also his/her knowledge about production, the customers and clients who were loyal to the employee, information on current projects and the past history of the organization. Even though retention has been measured in financial terms many times, it can also be measured through the combination of some other factors (Ramlall 2003).
Several factors have been suggested as being helpful in retaining employees. Among these factors HRM practices, such as training and development and support by the supervisors are known to be of key importance. In order to retain employees, it is important that an organization uses proper HR practices i.e. training and development and the support of the supervisors (Walia and Bajaj 2012). In an attempt to better explain why employees have been less committed to their employers, the use of proper HRM practices (i.e. training and development and supervisors support) were advocated (Saba 2011; Sohail and Delin 2013). Moreover, the social exchange theory (Blau 1964), also provides a basis for linking training and development and supervisors support with the employees retention; when employees feel they receive benefits from their organization, they in turn will repay this with their commitment to stay with the organization for a longer period of time (Liao 2011).

In particular, this study will endeavor to contend how training and development and supervisors support are theoretically significant in improving the retention of employees, thus adding to the current literature on the part of training and development and supervisors support in the employees retention. Moreover, this study offers theoretical clarification of the part the work environment plays in moderating the association between training and development, supervisors support and employees retention. This paper additionally explains that the past studies conducted into the role of HRM practices in influencing employees' retention have conflicting results, and proposes that a moderator may be able to better clarify the relationship. 


\section{Literature Review}

\section{Employees Retention}

The problem of low retention rates is not new, and has always been a challenge for employers. The scholarly debate about employee retention stems from the 1900s when scholars and psychologists begin to identify various reasons that affect an employee's level of interest in his/her job, and the possible alternative opportunities (Rowland and Ferris 1982). Employees' retention has been defined in different ways by different researchers. Employee retention alludes to the different strategies and practices which cause workers to stay with an institution for a longer period of time (Singh and Dixit 2011). Similarly, according to Hom (1995), employee retention is a process through which employees are motivated to stay with the organization for longer periods of time. Human resource are one of the most valuable and significant resources for any organization, and are what makes the organization work in a vastly improved manner, keeping in mind the end goal is to achieve a competitive advantage; therefore retaining them in their jobs is necessary (Ng'ethe et al. 2012). Employee retention is thought be very beneficial for all organizations (Akila 2012). Research showed that replacing an old employee with a new one increases the operational costs because of the cost of finding and training the new employee (Dess and Shaw 2001).

Several scholars have undertaken studies to show the significance of employee retention. Denton (1992) argued that when there is a good match between the organization and the employee, it is easier to retain him/her. Carney (1998) found communication was the basic factor for retaining employ- ees. According to Tett and Meyer (1993), one of the main reasons to leave an organization is its psychological factors. Lynn (1997) argued that to retain its employees, an institute must provide career development opportunities that are more dynamic toward the accomplishment of their objectives and targets. According to Mendonsa (1998), benefits and rewards provide the basis for achieving a competitive advantage; however they are also significant elements for retaining employees in an organization.

It has been noted, from the literature, that although employees retention has been studied previously, these studies lack the comprehensiveness to explain the antecedents of employees retention, as most only focus on the different determinants rather than training and development and supervisors support. Therefore, this study will explain how training and development and supervisors support are important for enhancing employee retention, thus contributing to the existing literature on the role of training and development and supervisors support for employee retention.

\section{Training and Development}

Another important function of HRM practices is training and development. Training and development refers to the degree of training received by employees to develop their skills fromthe organization (Delery and Doty 1996). According to Schuler and MacMillan (1984) training and development is a human resource management practice that helps organizations to gain a competitive edge. Generally, it helps to increase the employees' levels of commitment and loyalty, causing them to stay for longer with the organization, hence it decreases turnover and enhances retention (Samuel and Chipunza 
2009). According to Forgacs, (2009) and Paré and Trembley (2007), training and development is one of the vital components of HRM practices that influence employees' levels of job satisfaction, which in turn, may affect their decision about staying with the organization. Similarly, the social exchange theory (Blau 1964), also supports this notion.

Previously, researchers demonstrated that when an organization provides sufficient training and development opportunities, its employees are more satisfied, and hence stay with the organization for a longer period of time (Chang 1999). In the same way, Martin (2003) also mentioned that an organization that provides training to improve its current employees' competency and skills easily manages to retain its employees. In line with the previous explanation, Winterton (2004) argued that failure to invest in training and development may contribute to lower rates of employee retention. Similarly, Lee and Bruvold (2003) found a significant correlation between training and development and employees retention. Similarly, Ahmad, Bibi and Majid (2017) probed the correlation between training and employee commitment in the context of Pakistan. They used the survey method for data collection; producing 246 items for analysis. The outcome of the data's analysis showed a significant relationship between training and commitment. In contrast, Haines et al. (2010) mentioned that training and development might decrease employee retention; by enhancing their skills it may make them more attractive to other organizations. Similarly, Batt et al. (2002) also argued that training and development does not positively influence employees' retention.

Hence, from the above discussion it is clear that there is still no clear explanation about the nature of the relationship between training and employee retention levels, as dif- ferent studies have reported inconsistent results. Hence, due to the conflicting results and lacking a clear explanation of the relationship's nature, further investigation is needed to better comprehend the relationship between training and employee retention. Thus this study proposes the Hypthesisi $1\left(\mathrm{H}_{1}\right)$ :

$H_{1}$ : Training and development is positively associated with employee retention.

\section{Supervisor Support}

Supervisors support refers to the interpersonal relationships between supervisors and subordinates (London 1993). As explained by Tan (2008) support from a supervisor includes the useful evaluation of one's performance, career mentoring, the development of one's career network and job direction. According to Bigliardi et al. (2005) and Lee (2004) the provision of such support should facilitate positive attitudes towards the organization in general, as supervisors act as agents of the organization. At the point where the relationship between employees and supervisors is characterized by obligations, trust, long term orientation and socio emotional resources, the employees perceive their supervisors support as a social exchange construct (Dysvik and Kuvaas 2012; Eisenberger et al. 2002,). As a result, when employees are treated nicely by their employers, they repay them with better attitudes and behavior (Meyer and Allen 1991). Ahmad, Bibi and Majid, (2016) also highlight that if employees receive adequate support from their supervisors, they will demonstrate positive behavior toward their organization in return.

Empirical studies have shown that supervisor support has a consistent, positive relationship with commitment and retention (Walumbwa et. al 2005). Based on the find- 
ings of Price and Muller (1986), employee retention is expected to be enhanced by supervisor support. Similarly, Silbert (2005) argued that talented employees have many opportunities to find a good job, workplace or position elsewhere; therefore, to retain these competent employees, organizations should create a friendly environment which promotes supervisor support. Moreover, Tuzun and Kalemci (2013) also prompted that supervisor support positively influences employee retention. However, while studying commercial bank employees in Bangladesh, Billah (2009) pointed out that there is no significant relationship between supervisory support and employees' decisions to stay. Moreover, Abeysekera (2007) mentioned that there is a non-significant relationship between supervisor support and employees retention in the Sri Lankan context.

Hence, from the above literature it is concluded that there is still no clear explanation about the nature of the relationship between supervisor support and employee retention. Moreover the conflicting results suggest a more detailed investigation of this association is needed (Cho et al. 2009). Therefore, this study proposes the Hypothesis 2 $\left(\mathrm{H}_{2}\right)$

\section{$H_{2}$ : Supervisor support is positively associated with employee retention.}

\section{Work Environment}

Working environment refers to the provision of a good and safe place to work (Edgar and Geare 2005). The work environment is one of the factors that affect employees' decisions to stay with the organization (Zeytinoglu and Denton 2005). The historical backdrop to the work environment can be found in the introductory work of Tolman (1926), while working on "cognitive maps."
He held that people try to understand their environment. Afterward, Lewin et al. (1939) added that an environment signifies mutual consideration of a cluster, about its surroundings. The work environment is a vital factor that influences employee commitment and retention (Umamaheswari and Krishnan 2016; Zeytinoglu et al. 2005). The working environment is denoted as a safe physical working atmosphere (Edgar and Geare 2005). The working environment tends to have positive or negative effects on certain job outcomes, like involvement, commitment and the intention to stay with the organization (Ollukkaran et al. 2012). According to Mangi et al., (2011) a good working environment, for example, an attractive and clean environment, encourages individual employees to complete their work more effectively and is expected to have a positive impact on the retention and commitment of the employees.

According to the social exchange theory (Blau 1964) proper training, development and supervisors support, organized by an organization should theoretically be able to enhance employee retention rates, as individuals and organizations enter into exchange relationships in which the provision of mutual benefits creates obligations to reciprocate (Raihan 2012). However, empirical results on the effects of HRM practices (i.e., training, development and supervisors support) on employees retention appear mixed (Abeysekera (2007); Billah (2009); Dockelet al. (2006); Haines et al., (2010); Hatton and Emerson (1998); Lee et al. (2006)). Based on the contradictory findings of prior studies, the working environment will be incorporated as a moderator for the relationship between training and development, supervisors support, and employees' retention in the current study. This is in accordance with Baron and Kenny's (1986) statement that when there is a weak 
or inconsistent relationship between the criterion and predictor variable, it is suggested a moderating variable be incorporated. Similarly, Jaworski (1988) contended that the adequacy of different control mechanisms may be dependent upon internal and external contingency variables. Hence, this suggests the need for a moderator variable. Therefore, in order to better understand the influence of training and development, and supervisors support on employee retention, this study suggests that the work environment might moderate the relationships.

Previous studies have examined the moderating role of the work environment on the relationship between entrepreneurial orientation and firm performance (Aaraki and Kimbugw 2015); Western expatriates' commitment and retention in international assignments (Nguyen et al. 2013) and motivation to learn and perceived training transfer (KimSoon, Ahmad and Ahmad 2014); all suggesting that it has the ability to moderate the relationship between predictor and criterion variables. Moreover, the literature shows that no study has been done with the work environment as the moderator for the relationship between training, development, supervisors support, and employee retention. Therefore, to fill this gap, this study considers the work environment as the moderator to further investigate this relationship.

Moreover, the social exchange theory (Blau 1964) also supports this phenomenon by arguing that individuals and organizations enter into exchange relationships in which the provision of mutual benefits creates the obligation to reciprocate. When the organization provides a proper working environment the employees will feel obligated to repay in the form of loyality and remain with the organization (Setton et al.1996). Therefore, this study proposes the Hypothesis $3\left(\mathrm{H}_{3}\right)$, and Hypothesis $4\left(\mathrm{H}_{4}\right)$

$H_{3}$ : The work environment will moderate the relationship between training and development and employees' retention.

$H_{4}$ : The work environment will moderate the relationship between supervisors support and employees' retention.

\section{Social Exchange Theory}

The Social Exchange Theory (SET), which was developed originally by Thibaut and Kelley in 1959, is used in the current study. It has been utilized increasingly as the theoretical base for turnover and retention research to comprehend the employer/employee relationship (Coyle-Shapiro and Conway 2005). SET postulates that good acts and performance must be reciprocated (Blau 1964). According to Mossholder et al. (2005), SET suggests that a person who feels that he/she receives benefits from someone will feel obligated to repay or compensate that person through positive behavior, attitudes, efforts and devotion. Moreover, the SET (Blau 1964) states that institutions utilize different HRM practices (i.e., training and development, and supervisors support) that provide distinct exchange relationships. Furthermore, the SET described that employees perform better when they are supported and valued by their organization (Eisenberger et al. 2001).

\section{Research Framework}

Based on the above literature review, the proposed research framework for this study, illustrating the moderating effect of the working environment on the relationship between training, development, supervisors 
Figure 1. Research Framwork

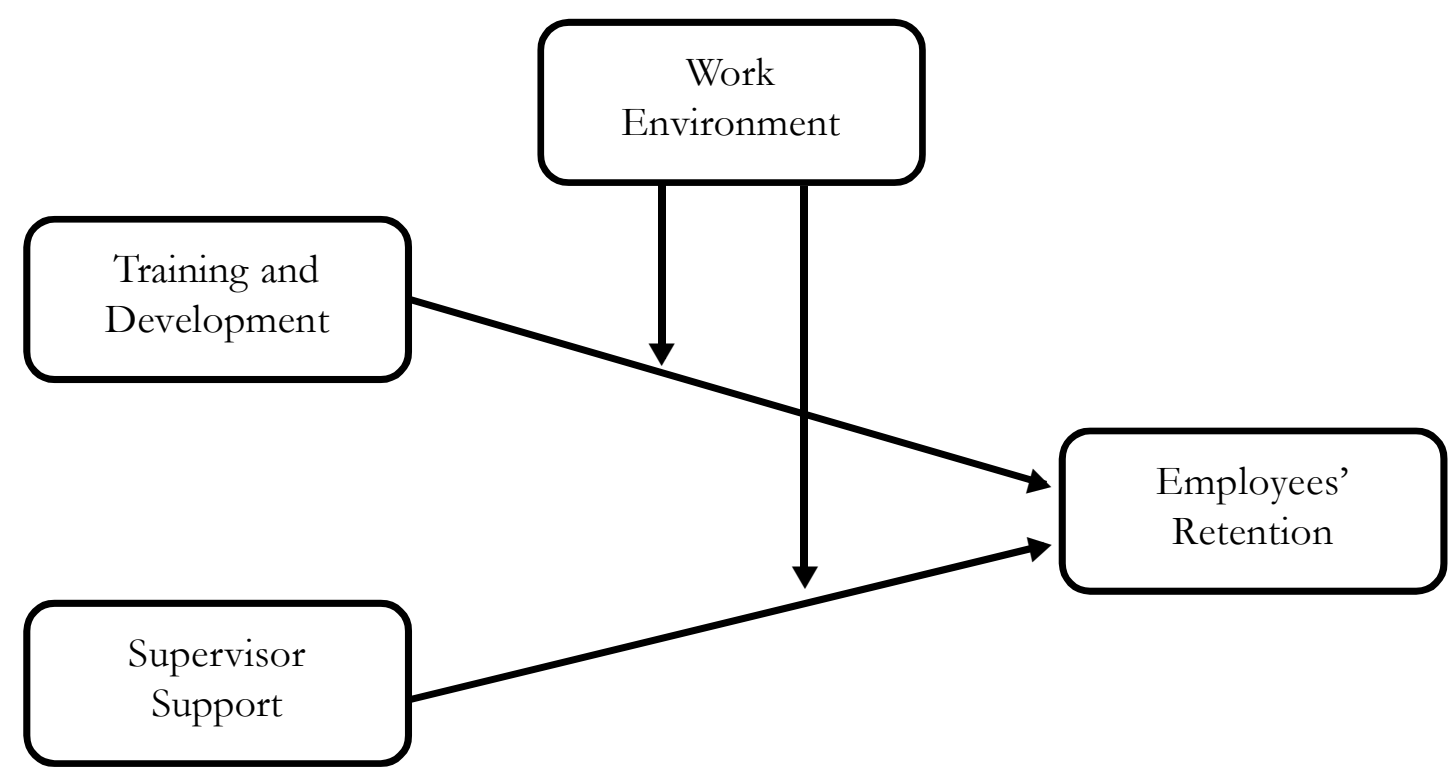

support and employees' retention is presented in Figure 1.

In explaining the moderating role of the work environment on this relationship, the present paper proposes that the extent to which training and development and supervisors support affects the employees retention varies, depending upon the work environment provided by the organization. Given the empirical support for the social exchange theory across various organizational settings, it is proposed that this theory would provide empirical support for the moderating role of the work environment on the relationship being studied.

\section{Methods}

\section{Participants and Respondents' Profiles}

Out of 380 questionnaires distributed among faculty members in public higher education institutes in Pakistan, only 270 ques- tionnaires were returned out of which 250 were usable and used for further analysis. The survey measured compensation, promotional opportunities and employees' retention. Out of the 250 respondents, 85 percent were males, the remaining 15 percent were females; 65.5 percent were lecturers, 28.5 percent assistant professors; 5 percent associated professors and only 1 percent professors. Most of the respondents $(72 \%)$ hold Ms/M.Phil degrees; 24 percent hold master's degrees and the remaining 4 percent hold a doctorate degree. 68 percent of the respondents were married while the remaining 32 percent were single. The mean age of the respondents was 35 years.

\section{Measurement}

The 27 items used in the present study were drawn and modified from previous studies. A seven point Likert scale was used to measure all the items, where 1 showed strongly disagree and 7 specified strongly agree. To measure employees retention lev- 
els, eleven items were adapted from Kyndt et al. (2009). A sample item is "I intend to remain working in this institute". Four items measuring training and development were adapted from Delery and Doty, (1996) for example "My institution provides extensive training for faculty development;" while eight items measuring the level of support by the supervisors were adapted from London (1993). A sample item is "My head of department demonstrates trust and confidence in me." To measure the work environment, four items were adapted from Edgar and Geare (2005). A sample item is "The work environment at my institution is good."

\section{Results}

\section{Convergent Validity}

In the current study, Smart PLS version 2.0 was used to analyze the data, and the researcher inspected it for the convergent validity. However, to assess the convergent va- lidity, Hair et al. (2010) suggested using three types of estimations viz. factor loadings, Average Variance Extracted (AVE) and Composite Reliability (CR). Firstly, the loadings of all the items are observed and a loading value of 0.50 or more is suggested as suitable in the literature (Hair et al. 2010), which can be seen in Table 1. Thus, out of 27 items, two items were deleted (RET-10; RET-11) because these items' loadings were observed to be below 0.40 , while the remaining 25 items were retained as these had loadings greater than 0.50 . Secondly, the composite reliability was examined, which shows the degree to which the items consistently seek to indicate the latent construct (Hair et al. 2010). The CR values ranged from 0.918 to 0.952 , as shown in Table 1, which exceeded the recommended value of 0.7 (Hair et al. 2010). Thirdly, the Average Variance Extracted (AVE) exceeded 0.5 and the factor loadings for all the items were above 0.5 , as recommended by (Barclay et al. 1995; Hair et al. 2010).

\section{Table 1. Results of Measurement Mode}

\begin{tabular}{|c|c|c|c|c|}
\hline Construct & Item & Loading & CR & AVE \\
\hline \multirow[t]{5}{*}{ Employees Retention } & $\begin{array}{l}\text { 1. I am planning to work } \\
\text { for another institution. }\end{array}$ & 0.865 & 0.952 & 0.689 \\
\hline & $\begin{array}{l}\text { 2. My work gives me } \\
\text { satisfaction within this } \\
\text { institution. }\end{array}$ & 0.905 & & \\
\hline & $\begin{array}{l}\text { 3. If I want to do another } \\
\text { job or function, I } \\
\text { would look first at the } \\
\text { possibilities within this } \\
\text { institution. }\end{array}$ & 0.834 & & \\
\hline & $\begin{array}{l}\text { 4. I see a future for } \\
\text { myself within this } \\
\text { institution. }\end{array}$ & 0.785 & & \\
\hline & $\begin{array}{l}\text { 5. It doesn't matter if I } \\
\text { am working for this } \\
\text { institution or another, } \\
\text { as long as I have work. }\end{array}$ & 0.910 & & \\
\hline
\end{tabular}


Table 1. Continued

\begin{tabular}{|c|c|c|c|c|}
\hline Construct & Item & Loading & CR & AVE \\
\hline & $\begin{array}{l}\text { 1. If it is up to me, I will } \\
\text { definitely be working } \\
\text { for this institution for } \\
\text { the next five years. }\end{array}$ & 0.914 & & \\
\hline & $\begin{array}{l}\text { 2. If I could start over } \\
\text { again, I would choose } \\
\text { to work for another } \\
\text { institution. }\end{array}$ & 0.734 & & \\
\hline & $\begin{array}{l}\text { 3. If I received an } \\
\text { attractive job offer } \\
\text { from another } \\
\text { institution, I would } \\
\text { take the job. }\end{array}$ & 0.767 & & \\
\hline & $\begin{array}{l}\text { 4. The work that I am } \\
\text { doing is very important } \\
\text { to me. }\end{array}$ & 0.730 & & \\
\hline \multirow[t]{7}{*}{ Supervisors Support } & $\begin{array}{l}\text { 1. My head of } \\
\text { department } \\
\text { demonstrates trust and } \\
\text { confidence in me }\end{array}$ & 0.681 & 0.918 & 0.587 \\
\hline & $\begin{array}{l}\text { 2. My head of } \\
\text { department treats me } \\
\text { with dignity and } \\
\text { respect. }\end{array}$ & 0.617 & & \\
\hline & $\begin{array}{l}\text { 3. My head of } \\
\text { department gives me } \\
\text { authority that I need to } \\
\text { do the job. }\end{array}$ & 0.630 & & \\
\hline & $\begin{array}{l}\text { 4. My head of } \\
\text { department provides } \\
\text { me with a useful } \\
\text { performance appraisal. }\end{array}$ & 0.884 & & \\
\hline & $\begin{array}{l}\text { 5. My head of } \\
\text { department provides } \\
\text { me to with ongoing } \\
\text { feedback. }\end{array}$ & 0.849 & & \\
\hline & $\begin{array}{l}\text { 6. My head of } \\
\text { department jointly sets } \\
\text { performance objectives } \\
\text { with me. }\end{array}$ & 0.687 & & \\
\hline & $\begin{array}{l}\text { 7. My head of } \\
\text { department helps me } \\
\text { develop my career } \\
\text { plan. }\end{array}$ & 0.878 & & \\
\hline
\end{tabular}


Table 1. Continued

\begin{tabular}{|c|c|c|c|c|}
\hline Construct & Item & Loading & CR & AVE \\
\hline \multirow{5}{*}{$\begin{array}{l}\text { Training and } \\
\text { Development }\end{array}$} & $\begin{array}{l}\text { 8. My head of } \\
\text { department provides } \\
\text { adequate time for me } \\
\text { to attend training. }\end{array}$ & 0.845 & & \multirow{5}{*}{0.739} \\
\hline & $\begin{array}{l}\text { 1. My institution provides } \\
\text { extensive training for } \\
\text { the faculty's } \\
\text { development. }\end{array}$ & 0.703 & 0.918 & \\
\hline & $\begin{array}{l}\text { 2. My institution provides } \\
\text { developmental training } \\
\text { programs for the } \\
\text { faculty every year. }\end{array}$ & 0.862 & & \\
\hline & $\begin{array}{l}\text { 3. In my institution, there } \\
\text { is formal } \\
\text { developmental training } \\
\text { to teach new academic } \\
\text { staff the skills they } \\
\text { need to perform their } \\
\text { jobs. }\end{array}$ & 0.937 & & \\
\hline & $\begin{array}{l}\text { 4. My institution provides } \\
\text { formal developmental } \\
\text { training to faculty } \\
\text { members in order to } \\
\text { increase their chances } \\
\text { of promotion in this } \\
\text { institution. }\end{array}$ & 0.917 & & \\
\hline \multirow[t]{4}{*}{ Work Environment } & $\begin{array}{l}\text { 1. The work environment } \\
\text { at my institution is } \\
\text { good. }\end{array}$ & 0.867 & 0.939 & \multirow[t]{4}{*}{0.793} \\
\hline & $\begin{array}{l}\text { 2. My health has not } \\
\text { suffered as a result of } \\
\text { working for this } \\
\text { institution. }\end{array}$ & 0.933 & & \\
\hline & $\begin{array}{l}\text { 3. I always feel safe } \\
\text { working here in this } \\
\text { environment. }\end{array}$ & 0.914 & & \\
\hline & $\begin{array}{l}\text { 4. This institution does } \\
\text { everything to ensure } \\
\text { the well-being of its } \\
\text { academic staff }\end{array}$ & 0.845 & & \\
\hline
\end{tabular}




\section{Discriminant Validity}

The discriminant validity in this study is accomplished by analyzing the correlation of the latent construct with the square root of the AVE (Duarte and Raposo 2010; Fornell and Larcker 1981). In the same vein, the discriminant validity is also realized by matching the outer loading with the cross loading (Hair et al. 2013).

As presented in Table 2, the diagonal values are greater than the other values of the columns and rows in which they are situated, confirming the discriminant validity of the outer model (Hair et al. 1998; Hair et al. 2010).

\section{Structural Model}

Figure 2 is the measurement model was the structural model. There is a significant relationship between training and development and employees retention, as presented in Table 3, (beta $=0.204, \mathrm{t}=2.394$ and $\mathrm{p}<$ 0.01). The results also show that there is an imperative and positive relationship between supervisors support and employees retention, (beta $=0.134, \mathrm{t}=2.032$ and $\mathrm{p}<0.02$ ).

Table 2. Discriminant Validity of Constructs

\begin{tabular}{lcccc}
\hline & RET & SS & TD & WE \\
\hline Retention & $\mathbf{0 . 8 3 0 1 1}$ & & & \\
Supervisors Support & 0.168174 & $\mathbf{0 . 7 6 6 4 7}$ & & \\
$\begin{array}{l}\text { Training and } \\
\text { Development }\end{array}$ & 0.199717 & -0.519 & $\mathbf{0 . 8 5 9 6 5}$ & \\
Work Environment & 0.188705 & 0.420744 & -0.33103 & $\mathbf{0 . 8 9 0 4 5}$ \\
\hline
\end{tabular}

Figure.2. Structural Model

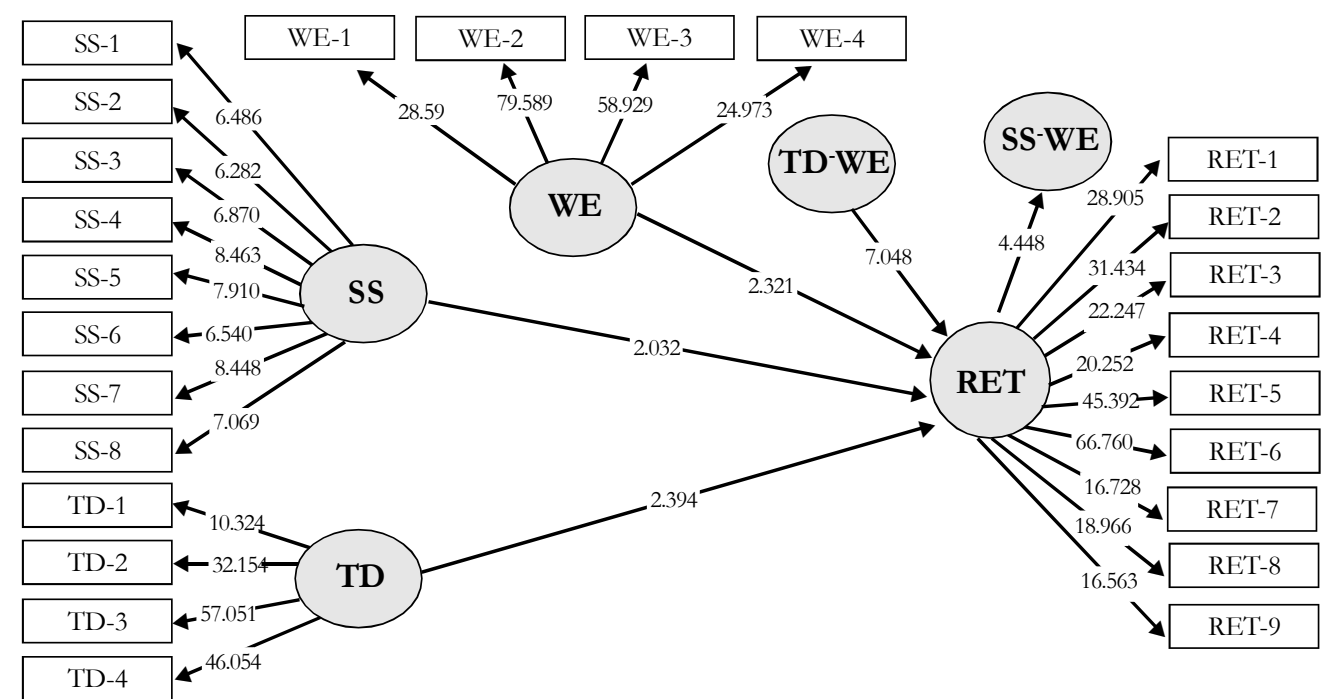


Table 3. Path Coefficients and Hypothesis Testing

\begin{tabular}{|c|c|c|c|c|c|c|}
\hline Hypothesis & Relationship & $\begin{array}{c}\text { Beta } \\
\text { value }\end{array}$ & $\begin{array}{l}\text { Standard } \\
\text { Error } \\
\text { (STERR) }\end{array}$ & $\begin{array}{l}\text { T- } \\
\text { Statistic } \\
\text { s }\end{array}$ & P-VALUE & Decision \\
\hline H1 & $\begin{array}{c}\text { Training and } \\
\text { Development } \rightarrow \text { Retention }\end{array}$ & 0.204 & 0.085 & 2.394 & 0.01 & Supported \\
\hline H2 & $\begin{array}{c}\text { Supervisor } \\
\text { Support } \rightarrow \text { Retention }\end{array}$ & 0.134 & 0.066 & 2.032 & 0.02 & Supported \\
\hline H3 & $\begin{array}{c}\text { Training and Development* } \\
\text { Work } \\
\text { environment } \rightarrow \text { Retention }\end{array}$ & 0.404 & 0.057 & 7.048 & 0.00 & Supported \\
\hline $\mathbf{H} 4$ & $\begin{array}{l}\text { Supervisor Support } * \text { Work } \\
\text { environment } \rightarrow \text { Retention }\end{array}$ & 0.435 & 0.098 & 4.448 & 0.00 & Supported \\
\hline
\end{tabular}

Note: ${ }^{* *} \mathrm{p}<0.01$

Figure 3. Interaction effect of Work environment on Training and Development and Employee Retention

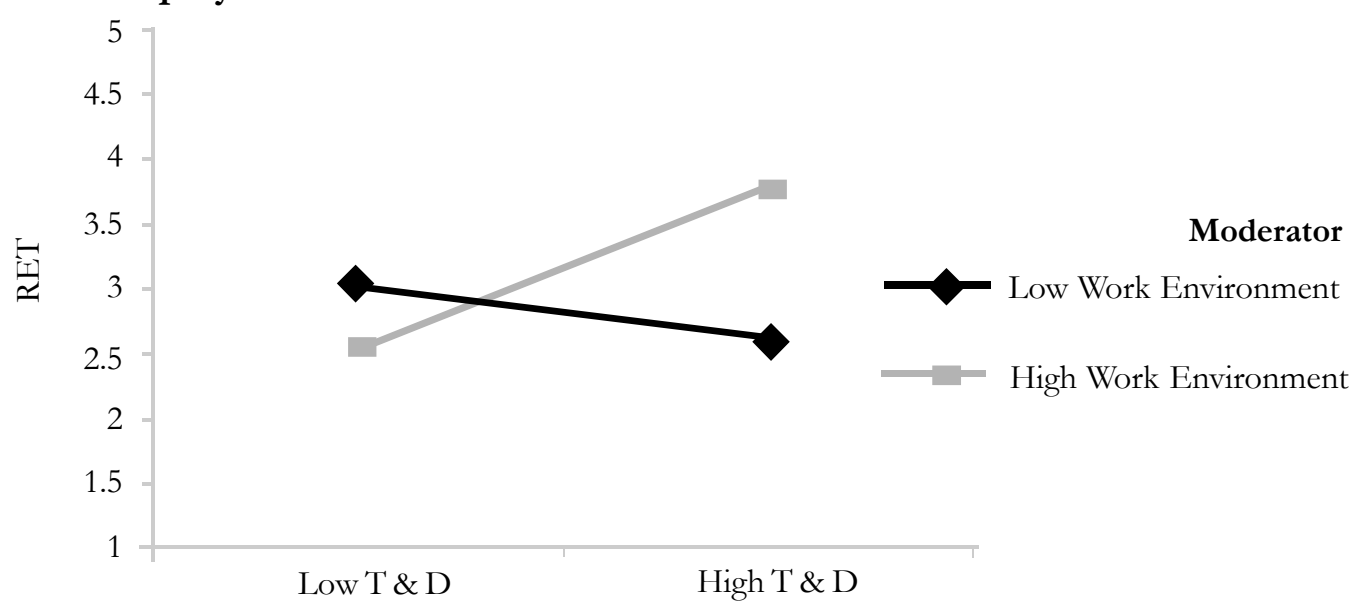

Figure 4. Interaction Effect of Work Environment on Supervisors Support and Retention

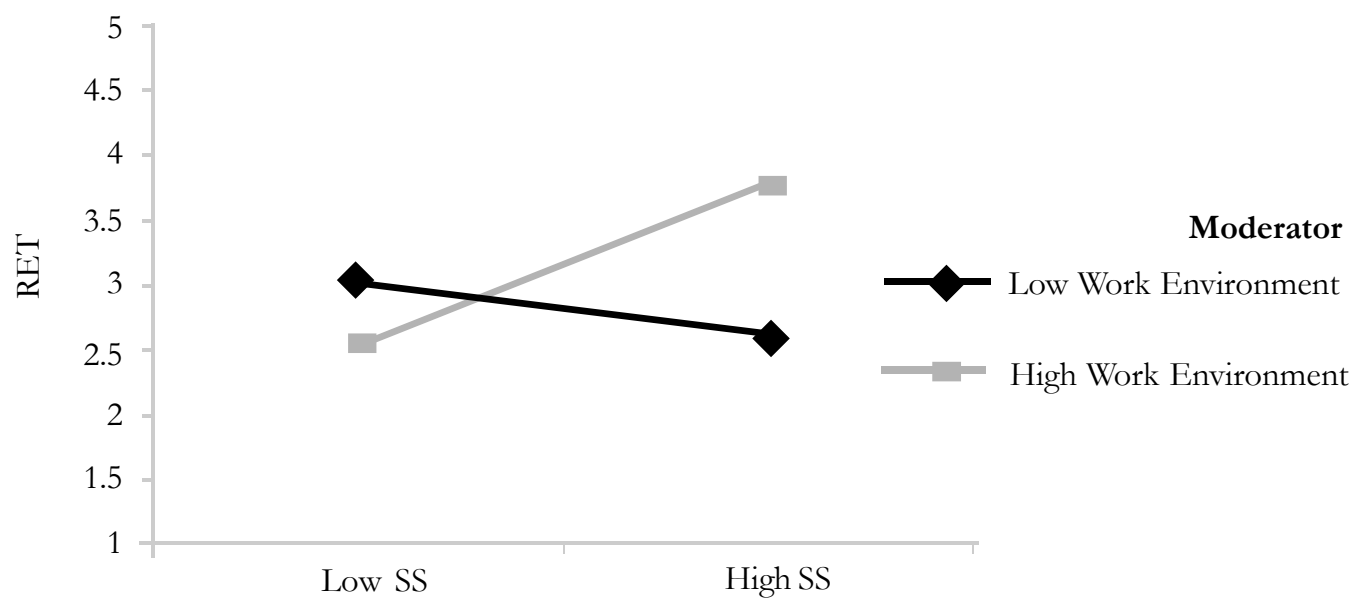


The results also show that the work environment moderates the relationship between training and development and employee retention, (beta $=0.404, \mathrm{t}=7.048$ and $\mathrm{p}<0.00)$. Figure 3 shows the moderating effect of the work environment on the relationship between training, development and the retention of employees; this relationship is stronger for individuals in public universities with a highly conducive working environment than it is for individuals in public universities with a less conducive work environment.

Similarly, Table 3 and Figure 4 also reveal that the work environment moderates the relationship between supervisors support and retention, $($ beta $=0.435, \mathrm{t}=4.448$ and $\mathrm{p}$ $<0.00)$. This relationship is stronger for individuals in public universities with a highly conducive work environment than it is for individuals in public universities with a less conducive work environment. Furthermore, the $\mathrm{R}^{2}$ value was 0.17 , which suggests that the modeled variables can explain 17 percent of the variance in the employee retention rate.

\section{Discussion}

This current study examined the influence of training and development and supervisors support on employees' retention among academic faculty members in public higher education institutions in Pakistan. The findings of this study revealed a significant positive relationship between training and development and employee retention. This finding is consistent with the results of previous research (e.g., Choi and Dickson 2009; Saritas 2007). This suggested that when organizations provide adequate training programs and care about their employees, it makes the em- ployees stay for longer periods of time and enhances their retention rate (Dockel et al. 2006). The findings were also supported by SET which implies that when employees receive proper training from an organization, they are more satisfied and feel obligated to repay this through their positive attitudes, loyalty and devotion (Blau 1964; Mossholder et al.2005).

Moreover, the finding of this study also indicated a positive significant relationship between supervisors support and employee retention. This finding is also in line with the results of previous studies (e.g., Clear and Dickson 2005; Schleh 1977). It indicates that when employees receive sufficient support from their supervisors, they remain for a longer period with that particular organization (Zhao and Zhou 2008). The SET also supported the findings by arguing that when organizations provide adequate support from their supervisors, in turn the employees will show more loyalty and will stay with the organizations (Woo and Chelladurai 2012).

Additionally, the findings also revealed that the work environment buffers the relationship between training and development and employee retention rates. Additionally, the study by Sutherland, (2004) suggested that organizations should focus on creating supportive work environments to keep talented employees in the organizations for longer periods of time. Thus, it means that the work environment plays a key role in motivating and retaining the employees and indicates that when academic staff receive a competitive salary, as well as support from their organization by providing them with a conducive work environment, this all helps to enhance the commitment level of the employees, specifically public university academic staff. 
Similarly, the results of the structural modeling revealed that the work environment moderates the relationship between supervisors support and employee retention. Previous studies such as those by Kyndt et al. (2009) and Irshad (2000) highlighted that the work environment significantly affected employees' retention. It means that an organization that provides a highly conducive work environment, where the employees feel more driven, has a higher level of employee retention than those who have a less conducive work environment, such as in the public sector universities in Pakistan.

\section{Implications}

On the premise of the above results, there are a couple of suggestions and implications for the administration and management of public Higher Education Institutions (HEIs) and their faculty members. Theoretically, this study has provided some empirical evidence on the relationship between training and development, supervisors support, and employees' retention.

One of the main theoretical contributions of the present study is in the introduction of the work environment as a moderating variable to better explain and understand the relationship between training, development, supervisors support, and employee retention. The outcomes of the present study have also contributed to the knowledge and literature on employee retention. The findings confirmed the notion that training and development and support by supervisors are of the utmost significance in increasing faculty retention rates, which covers the practical importance of this study for the policy makers and practitioners.
Furthermore, there are a few implications for human resource managers and policy makers in public higher institutions in Pakistan, as they decide how to allocate resources and retain competent staff. Firstly, the present study suggests that training and development is the main resource for enhancing employee retention rates. The HR department and HEIs need to ascertain that there is a proper training system for the faculty members. When they feel that they receive proper training, they stay for a longer period of time at the institution (Tsai and Tai 2003).

Secondly, supervisors support was also found to be significantly related with employee retention rates. Therefore, the management of the higher education institutions needs to provide adequate support to their faculty members, which will enhance their loyalty (Zhao and Zhou 2008). Similarly, Meyer and Allen, (1991) also found that adequate supervisors support enhances the retention of employees.

Moreover, HR departments and HEIs should also understand the moderating effect of the work environment on the relationship of training, development, supervisors support, and employee retention. This means that the working environment plays a vital role in enhancing the employees' retention, and indicates that when faculty members are provided with a conducive work environment, training and development, and supervisors support by the organization, it helps to enhance the commitment level of the academic staff and makes them stay for a longer period of time with the organization, especially in the public sector universities in Pakistan. 


\section{Limitations and Suggestions for Future Research}

The limitations of this study: Firstly, only the academic faculty members were considered as the respondents in the current study. Thus, the findings may be generalized by selecting non-academic staff members as respondents in future research. Other sectors such as services and manufacturing sectors should also be investigated in future research. Secondly, data were only collected from academic faculties in Khyber Pakhtunkhwa province in Pakistan because of time limitations and financial constraints. Hence, future research can be extended to other areas in $\mathrm{Pa}$ kistan. Thirdly, the present study considered a cross sectional approach, future studies may consider a longitudinal method. And finally, this study reported $\mathrm{R}^{2}$ values of 17 percent for the variance of the employees' retention, suggesting that training, development and supervisors support are not the only predictors of employee retention rates. Therefore, future studies should integrate some other variables such as job security, employees' trust and organizational behavior.

\section{References}

Aarakit, S. M., and F. K. Kimbugwe. 2015. Moderating effect of organizational environment on intrapreneurial orientation and firm performance. Global Advanced Research Journal of Management and Business Studies 4 (7): 285-290.

Abbasi, S. M., and K. W. Holman,. 2000. Turnover: The real bottom line. Public Personnel Management 29 (3): 333-342.

Abeysekera, R. 2007. The impact of human resource management practices on marketing executive turnover of leasing companies in Sri Lanka. Contemporary Management Research 3 (3): 233-252.

Ahmad, A., P. Bibi, and A. H. Majid. 2016. Co-worker support as moderator on the relationship between compensation and transactional leadership in organizational commitment. International Journal of Economic Perspectives 10 (4): 695-709.

Ahmad, A., P. Bibi, and A. H. Majid .2017. The impact of training and development and transformational leadership over organizational commitment among academic staff in public tertiary institutions: The buffering role of coworker support. International Journal of Economic Perspectives 11 (1): 417-432.

Akila, R. 2012. A Study on employee retention among executives at BGR Energy systems LTD, Chennai. International Journal of Marketing, Financial Services and Management Research 1 (9): 18-32.

American Management Association (AMA). 2001. Survey finds cash not the best retention tool. HR Focus $76(6): 4$.

Barclay, D, C. Higgins, and R. Thompson. 1995. 'The partial least square (PLS) approach to causal modelling: personal computer adoption and use as an illustration. Technology Studies 2 (2): 285-309.

Baron, R. M., and D. A. Kenny. 1986. The moderator-mediator variable distinction in social psychological research: Conceptual, strategic, and statistical considerations. Journal of Personality and Social Psychology 51 (6): 1173-1186. 
Batt, R., J. S. Alexander, A. Colvin, and J. Keefe. 2002. Employee voice, human resource practices, and quit rates: Evidence from the telecommunications industry. Industrial and Labor Relations Review 55: 573-594.

Bigliardi, B., A. Petroni, and A. I. Dormio. 2005. Status, role and satisfaction among development engineers. European Journal of Innovation Management 8 (4): 453-470.

Billah, M. M. 2009. Human resource management practices and employee turnover intention to leave: A Study on commercial banks in Bangladesh. AMDIB Management Review 1: 23-42.

Blau, P. M. 1964. Exchange and Power in Social Life. New York, NY: Wiley.

Carney, K. 1998. How Businesses Can Reduce High Employee Turnover. Inc, 47.

Chang, E. 1999. Career commitment as a complex moderator of organizational commitment and turnover intention. Human Relations 52: 1257-1278.

Cho, S., M. M. Johanson, and P. Guchait. 2009. Employee intent to leave: A comparison of determinants of intent to leave versus intent to stay. International Journal of Hospitality Management 28 (3): 374-381.

Choi, Y., and D. R. Dickson. 2009. A case study into the benefits of management training programs: Impacts on hotel employee turnover and satisfaction level. Journal of Human Resources in Hospitality and Tourism 9 (1): 103-116.

Clear, F., and D. Dickson. 2005. Teleworking practices in small and medium-sized firms: Management style and worker autonomy. New Technology, Work and Employment 20 (3): 218-233.

Coyle-Shapiro, J. A. M., and N. Conway. 2005. Perceived organizational support and employee diligence, commitment and innovation. Journal of Applied Psychology 90: 774-781.

Delery, J. E., and D. H. Doty. 1996. Modes in theorizing in strategic HRM: Tests of universalistic, contingencies, and configurational performance predictions. Academy of Management Journal 39: 802-835.

Denton, D. K. 1992. Recruitment, Retention, and Employee Relations: Field-tested Strategies for the'90s. Praeger Pub Text.

Dess, G. D. and J. D. Shaw. 2001. Voluntary turnover, social, capital, and organizational performance. Academy of Management Review 26 (3): 446-456.

Dockel, A., J. S. Basson, and M. Coetzee. 2006. The effect of retention factors on organizational commitment: An investigation of high technology employees. SA Journal of Human Resource Management 4 (2): 20-28.

Duarte, P., and M. Raposo. 2010. A PLS model to study brand preference: An application to the mobile phone market. In V. Esposito Vinzi, W. W. Chin, J. Henseler and H. Wang (Eds.), Handbook of Partial Least Squares (pp. 449-485): Springer Berlin Heidelberg.

Dysvik, A., and B. Kuvaas. 2012. Perceived job autonomy and turn over intention: The moderating role of perceived supervisor support. European Journal of Work and Organizational Psychology. DOI:10.1080/ 1359432X.2012.667215.

Edgar, F., and A. Geare. 2005. HRM practice and employee attitudes: Different measures- different results. Personnel Review 34 (5): 534-549.

Eisenberger, R., S. Armeli, B. Rexwinkel, P. D. Lynch, and L. Rhoades.2001. Reciprocation of perceived organizational support. Journal of Applied Psychology 86 (1): 42-51. 
Eisenberger, R., F. Stinglhamber, C. Vandenberghe, I. Sucharski, and L. Rhoades. 2002. Perceived supervisor support: Contributions to perceived organizational support and employee retention. Journal of Applied Psychology 87 (3): 565-573.

Forgacs, L. 2009. Recruitment and retention across continents. Journal of Training and Development 63 (6): 40-44.

Fornell, C., and D. F. Larcker. 1981. Evaluating structural equation models with unobservable variables and measurement error. Journal of Marketing Research 18: 39-50.

Haines, V. Y., P. Jalette, and K. Larose.2010. The influence of human resource management practices on employee voluntary turnover rates in the Canadian non-governmental sector. Industrial and Labor Relations Review 63 (2): 228-246.

Hair, J. F. J., R. E. Anderson, R. L. Tatham, and W. C. Black. 1998. Multivariate Data Analysis (5 ${ }^{\text {th }}$ ed.). Prentice Hall, Upper Saddle River, New Jersey.

Hair, J. F., C. B. William, J. B. Barry, and E. A. Rolph. 2010, Multivariate Data Analysis. Englewood Cliffs, NJ: Prentice Hall.

Hair, J. F., G. T. M. Hult, C. M. Ringle, and M. Sarstedt. 2013. A Primer on Partial Least Squares Structural Equation Modeling (PLS-SEM). Sage: Thousand Oaks.

Harris, J., and J. Brannick. 1999. Finding and Keeping Great Employees (Vol. 314). New York: Amacom.

Hatton, C., and E. Emerson. 1998. Brief report: Organizational predictors of actual staff turnover in a service for people with multiple disabilities. Journal of Applied Research in Intellectual Disabilities 5: 166171.

Hom, P. W., and R. W. Griffeth. 1995. Employee turnover. South-Western Pub.

Irshad, M., and F. Afridi. 2010. Factors affecting retention: Evidence from literature. Abasyn Journal of Social Sciences 4 (2): 307-339.

Irshad, M. 2000. Factors affecting employee retention: Evidence from literature review. Abasyn Journal of Social Science 4 (1): 84-102.

Jaworski, B. J. 1988. Toward a theory of marketing control: Environmental context, control types, and consequences. The Journal of Marketing 52: 23-39.

Kim-Soon, N., N. Ahmad, and A. R. Ahmad. 2014. Moderating effects of work environment on motivation to learn and perceived training transfer: Empirical evidence from a bank. Australian Journal of Basic and Applied Sciences 8 (6): 344-361.

Kyndt, E., F. Dochy, M. Michielsen, and B. Moeyaert. 2009. Employee retention: Organisational and personal perspectives. Vocations and Learning 2 (3): 195-215.

Lee, C.H., and N. T. Bruvold. 2003. Creating value for employees: Investment in employee development. International Journal of Human Resource Development 14: 981-1000.

Lee, J. 2004. Effects of leadership and leader-member exchange on commitment. Leadersh. Org. Dev. J. 26: 655-672.

Lee, Y., J. Nam, D. Park, and K. A. Lee. 2006. What factors influence customer oriented prosocial behavior of customer-contact employees? Journal of Services Marketing 20 (4): 251-264.

Lewin, K., R. Lippitt, and R. White. 1939. Patterns of aggressive behavior in experimentally created social climates. Journal of Social Psychology 10: 271- 301. 
Liao, P. 2011. Linking work-family conflict to job attitudes: The mediating role of social exchange relationships. The International Journal of Human Resource Management 22 (14): 2965-2980.

London, M. 1993. Relationships between career motivation, empowerment, and support for career development. Journal of Occupational and Organizational Psychology 66 (1): 55-69.

Lynn, J. 1997. Hard to hold: Conquer the tight labor market by retaining valuable workers. Entrepreneur 34.

Mangi, R. A., H. J. Soomro, I. Ghumro, A. R. Abidi, and A. A. Jalbani. 2011. A study of job satisfaction among non Ph.D. faculty in universities. Australian Journal of Business and Management Research 1 (7): 83-90.

Martin C. 2003. Explaining labor turnover: Empirical evidence from UK establishments. Labor 17 (3): 391-412.

Mendonsa, R. 1998. Keeping who you want to keep: Retaining the best people. Supervision: 10-12.

Meyer, J., and N. Allen. 1991. A three-component conceptualization of organizational commitment. Human Resource Management Review 1: 64-98.

Mossholder, K. W., R. P. Settoon, and S. C. Henagan. 2005. A relational perspective on turnover: Examining structural, attitudinal, and behavioral predictors. Academy of Management Journal 48: 607-618.

Ng'ethe, J. M., M. E. Iravo, and G. S. Namusonge. 2012. Determinants of academic staff retention in public universities in Kenya: Empirical review. International Journal of Humanities and Social Science 2 (13): 205-212.

Nguyen, P., J. Felfe, and I. Fooken. 2013. Antecedents of commitment to a parent company and to a local operation: Empirical evidence from Western employees working for multinational companies in Vietnam. The International Journal of Human Resource Management 24 (7): 1346-1375.

Ollukkaran, B. A., and R. Gunaseelan. 2012. A study on the impact of work environment on employee performance. Namex International Journal of Management Research 2 (2).

Osteraker, M. C. 1999. Measuring motivation in a learning organization, Journal of Work. Place Learning.

Paré, G., and M. Tremblay. 2007. The influence of high-involvement human resources practices, procedural justice, organizational commitment, and citizenship behaviors on information technology professionals' turnover intentions. Group and Organization Management 32 (3): 326-357.

Price, J. L., and C. W. Muller. 1986. Handbook of Organizational Measurement. Marshfield, MA: Pitman.

Raihan, J. M. H. 2012. Mediating effects of organizational commitment and perceived organizational support on HRM practices and turnover intention: A study of private universities in Bangladesh. PhD Thesis. Universiti Utara Malaysia.

Ramlall, S. 2003. Organizational application managing employee retention as a strategy for increasing organizational competitiveness: Applied H.R.M. Research 8 (2): 63-72.

Rowland, K. M., and G. R. Ferris. 1982. Personnel Management. Boston, MA: Allyn and Bacon

Saba, I. 2011. Measuring the job satisfaction level of the academic staff in Bahawalpur Colleges. International Journal of Academic Research in Business and Social Sciences 1 (1): 1-8.

Samuel, M. O., and C. Chipunza. 2009. Employee retention and turnover: using motivational variables as a panacea. African Journal of Business Management 3 (8): 410-415.

Saritas, O. 2007. The Effects of Training and Development Activities on Employee Turnover: Turkish Insulation Sector.

Schleh, C. 1977. A matter of management style. Management Review 66 (8): 8-14. 
Schuler, R. S., and I. C. MacMillan. 1984. Gaining competitive advantage through human resource management practices. Human Resource Management 23 (3): 241-255.

Setton, R. P., N. Bennett, and R. C. Liden. 1996. Social exchange in organizations: Perceived organizational support, leader-member exchange, and employee reciprocity. Journal of Applied Psychology 81: 219227.

Silbert, L.2005. The Effect of Tangible Rewards on Perceived Organizational Support.

Sohail, M. T., and H. Delin. 2013. Job satisfaction surrounded by academics staff: A case study of job satisfaction of academics staff of the GCUL, Pakistan. Interdisciplinary Journal of Contemporary Research in Business 4 (11): 126-137.

Sutherland, M. M. 2004. Factors affecting the retention of knowledge workers. Ph.D. Dissertation. Faculty of Economics and Management Sciences, University of Johannesburg.

Tan, F. M. 2008. Organizational support as the mediator of career related HRM practices and affective commitment: Evidence from knowledge workers in Malaysia. Research and Practices in Human Resource Management 16 (2): 8-24.

Tett, R. P., and J. P. Meyer. 1993. Job satisfaction, organizational commitment, turnover intention, and turnover: Path analyses based on meta analytic findings. Pers. Psych. 46: 259-93.

Thibaut, J. W., and H. H. Kelley. 1959. The social Psychology of Groups. New York: John Wiley\& Sons.

Tolman, E. C. 1926. A behavioristic theory of ideas. Psychological Review 33 (5): 352-396.

Tsai, W-C., and W-T. Tai. 2003. Perceived importance as a mediator of the relationship between training assignment and training motivation. Personnel Review 32: 151-163.

Tuzun, I. K., and R. A. Kalemci. 2012. Organizational and supervisory support in relation to employee turnover intentions. Journal of Managerial Psychology 27 (5): 518-534.

Umamaheswari, S., and J. Krishnan. 2016. Work force retention: Role of work environment, organization commitment, supervisor support and training and development in ceramic sanitary ware industries in India. Journal of Industrial Engineering and Management 9 (3): 612.

Walia, B., and K. Bajaj. 2012. Impact of human resource management (HRM) practices on employee retention. International Journal of Research in IT \& Management 2 (2): 836-847.

Walumbwa, F. O., J. J. Lawler, B. J. Avolio, W. Peng, and S. Kan. 2005. Transformational leadership and work-related attitudes: The moderating effects of collective and self-efficacy across cultures. Journal of Leadership and Organizational Studies 11 (3): 2-16.

Winterton, J. 2004. A conceptual model of labor turnover and retention. Human Resource Development International 7 (3): 371-390.

Woo, B., and P. Chelladurai. 2012. Dynamics of perceived support and work attitudes: The case of fitness club employees. Human Resource Management Research 2 (1): 6-18.

Zeytinoglu, I. U., and M. Denton. 2005. Satisfied workers, retained workers: Effects of work and work environment on homecare workers' job satisfaction, stress, physical health, and retention. CHSRF FCRSS: Canadian Health Services Research Foundation, Foundation Canadienne de la Recherché sur les Services de Sante.

Zhao, W., and X. Zhou, X. 2008. Intra-organizational career advancement and voluntary turnover in a multinational bank in Taiwan. Career Development International 13 (5): 402-424. 
